
\title{
25 Research Suare \\ Effect of Land Use Change on Soil Carbon Stock and Selected Soil Properties in Gobu Sayyo, Western Ethiopia
}

mengistu welemariam ( $\sim$ mengistuwel@gmail.com )

Haramaya University College of Agricultural and Environmental Sciences https://orcid.org/0000-00026224-847X

Deginet Wako

Wollega University

Getahun Kitila

Wollega University

\section{Research}

Keywords: Soil carbon stock, land-use change, soil properties, land degradation, deforestation

Posted Date: June 15th, 2021

DOI: https://doi.org/10.21203/rs.3.rs-586121/v1

License: (c) (i) This work is licensed under a Creative Commons Attribution 4.0 International License.

Read Full License 


\section{Abstract}

Background: Land-use change is one of the major factors affecting soil degradation. The pressures of the human population on land resources have increased land-use change with more negative effects on soil carbon storage and soil properties. The objective of this study was to assess the effect of land-use changes on soil organic carbon (SOC) stock and selected soil physicochemical properties in Gobu Sayyo, Western Ethiopia. Soil samples were collected from three adjacent land uses i.e., forest land, grazing land, and cultivated lands at $0-20 \mathrm{~cm}$ and $20 \mathrm{~cm}-40 \mathrm{~cm}$ soil depths. A total of 36 composite soil samples were collected and the major soil properties and SOC storage of the area were analyzed and computed based on their standard procedures.

Results: Soil organic carbon stock was significantly $(p<0.05)$ higher $\left(43.09-81.86\right.$ tone ha-1 $\left.{ }^{-1}\right)$ in forest land and was significantly lower (38.08-43.09 tone $\left.\mathrm{ha}^{-1}\right)$ in cultivated land at the of depth of $0-20 \mathrm{~cm}$. SOC stock decreased with dept in all land uses. Changes in land use and soil depth affected the physical and chemical properties of soil. The physical soil property such as bulk density (BD) was higher $\left(1.62 \mathrm{gcm}^{-3}\right)$ in the cultivated land whereas, the lowest $\left(1.08 \mathrm{gcm}^{-3}\right)$ was recorded in the forest at $0-20 \mathrm{~cm}$ depth. Comparatively the moisture content was higher $(25.89 \%)$ under forest land at the depth of $20-40 \mathrm{~cm}$ and was lower (11.22\%) under cultivated lands. The chemical soil properties like exchangeable $\mathrm{Ca} 2+, \mathrm{Mg}^{2+}$, and $\mathrm{K}^{+}$were higher in forest lands. Organic carbon, avP, TN, ex. $\mathrm{Ca}^{2+}$, ex. $\mathrm{Mg}^{2+}$, ex. $\mathrm{K}^{+}$, and CEC were lower under cultivated lands. $\mathrm{pH}$ increased with depth and was higher under forest land and lower under cultivated land. Soils of the study area are in general acidic to slightly acid with $\mathrm{pH}$ value ranging from 46-6.02. The $\mathrm{pH}, \mathrm{SOC}, \mathrm{TN}$, av. Phosphorus and CEC were higher under forest land as compared to cultivated and grazing lands.

Conclusion: It can be concluded that soil organic carbon stocks, the physical and chemical properties were affected by land-use change and depth. Therefore, reducing the intensity of cultivation, adopting integrated soil fertility management, and maintaining forest land must be practiced to save the soil of the area from degradation.

\section{Introduction}

\subsection{Background}

Organic matter is a key component of the carbon cycle and represents the largest terrestrial repository of carbon globally (Liu et al. 2012). However, the capability of the soil to store and preserve organic matter has got much attention, to develop strategies to manage soils to increase their carbon storage and reduce the atmospheric carbon dioxide (McCarl and Schneider 2001).

Soil organic matter plays a key role in ensuring the long-term conservation of soil resources (Malo et al. 2005). Adequate levels of organic matter are essential to maintain or improve soil physical properties like 
soil porosity, infiltration capacity, moisture retention, and resistance to water and wind erosion (Izaurralde et al. 2001) and chemical properties like soil reaction and nutrient availability (Malo et al. 2005).

Soils store two or three times more carbon than that exists in the atmosphere as $\mathrm{CO}_{2}$ (Davidson et al. 2000) and 2.5 to 3 times as much as that stored in plants (Aniwek 2010). Man induced alterations affect not only the total carbon content of soils but also its distribution among the various pools (Liu et al. 2012), causing changes in the size distribution and stability of aggregates, as well as other soil properties (John et al. 2005).

Changes in land use and management have profound effects on the quantity and dynamics of soil organic matter and in turn, on the soil ecosystem functions (Liu et al. 2012). It has contributed to soil degradation and soil loss, leading to a decrease in soil carbon storage (Eaton et al. 2008). Land-use change due to deforestation in the tropics was the major contributor to $\mathrm{CO}_{2}$ emissions in the 1990s (IPCC 2001; UNFCCC 2007). Particularly, it is well studied that converting natural forests into agricultural fields leads to a decline in organic matter (Mengistu and Fassil 2010).

The pressures of the human population on land resources have increased land-use change with more negative effects on soil properties (Islam and Weil 2000). Land use transformation can affect soil physical and chemical properties. Soil nutrient availability is greater in forest land than in the cropland and pastures that replace them (Lal 2002). Forest conversion to cropland can also decrease soil properties such as soil texture, porosity, phosphorus content, CEC but increases soil bulk density (Heluf and Wakene 2006).

Most of the land-use changes in Ethiopia are due to direct and indirect human activities. These include overpopulation, deforestation, urbanization which led to the loss of natural resources (FAO 2008). Soil resources are prone to degradation due to misuse and mismanagement (Nega 2006). Besides, intensive agriculture and long term exploitative farm practices, have led to continuous depletion of natural vegetation cover and overutilization of land resources. Lack of agricultural inputs, traditional farming methods, and overgrazing aggravated the degradation of soil physical and chemical properties in Ethiopia (Heluf and Wakene 2006). On the other hand, integrated soil fertility management maintains the physicochemical properties of soils (Yitbarek et al. 2013).

Ethiopia was once covered with greater than $35 \%$ forest cover in the 1940 s. However, due to the increased human and livestock population, a large part of the forest is converted to farmlands and grazing lands. For sustainable utilization of natural resources, assessment of man-induced land-use change is therefore very important. Many studies have been conducted on the effect of land cover-land use change on soil properties in the country (Kiflu \& Beyene 2013; Wube \& Assen 2019; Aredehey et al. 2019). However, there is limited information on the effect of land-use change on SOC storage and soil properties in the western part of the country including Gobu Sayyo district.

Gobu Sayyo district in western Ethiopia has a large population size and shortage of farmland. The rapidly increasing population pressure in the district has led to vast changes in land use patterns mainly caused 
by increasing agricultural production at the expense of forest and grazing lands (GWAO 2009). Despite this problem, no research was done in the district on the effect of land-use change on soil properties. Thus, this study was undertaken to determine the effect of land-use changes on soil organic carbon stock and selected soil properties in the district.

\section{Materials And Methods}

\subsection{Description of the study area}

Gobu Sayyo is the district found in East Wollega Zone, Western Ethiopia at about $261 \mathrm{~km}$ from Addis Ababa the capital city of Ethiopia. It is located at $8^{0} 50^{\prime \prime} 0^{\prime} \mathrm{N}-9^{\circ} 40^{\prime \prime} \mathrm{O}^{\prime} \mathrm{N}$ and $36^{\circ} 30^{\prime \prime} 0^{\prime} \mathrm{E}-37^{\circ} 20^{\prime \prime} 0^{\prime} \mathrm{E}$ direction (Fig. 1). Most of the land has an elevation 1500m-1960m above sea level and characterized by subtropical climatic conditions with a mean annual temperature ranging $13^{0} \mathrm{c}-27^{0} \mathrm{C}$ and mean annual rainfall of $770 \mathrm{~mm}-1,657 \mathrm{~mm}$ (GSWCCFC 2018). According to the World Reference Base soil classification, the dominant soil types in the area include Alfisol and Nitisol (WRB 2006). The area has rugged topography. The population size of the district is about 57,455, where 27,268 (47.46\%) were males, whereas about 30,186 (52.53\%) were females as reported by Gobu Sayyo Health Center (GSHC 2019). Mixed livestock-crop production is the major farming system in the area.

Gobu Sayyo district has good vegetation cover than the other neighboring districts. There is a natural forest having a total area of about 1,381 hectares. However, there is a very serious deforestation (GSWAO 2018). According to Gobu Sayyo Woreda Agricultural Office, out of the total land of the district, the proximate areal coverage of land used for crop cultivations is 21,640 hectares, while 6,907 hectares is pasture or grazing land (GSWAO 2018)

\subsection{Sampling Technique, sample size and preparation}

Gobu Sayo district has eight kebeles. From a total of 8 kebeles in the district 2 kebeles (Gambella Tare and Ago Sombo) were selected purposively for the study because of their representativeness in terms of the extensive land-use changes that happened in the district. From the two kebeles, soil samples were collected from adjacent forest land, cultivated land, and grazing land at two soil depths $(0-20 \mathrm{~cm})$ and $(20 \mathrm{~cm}-40 \mathrm{~cm})$ in three replicates. Thirty-six (36) composite samples were collected in 2019.

The composite soil samples from representative sites of each land use were collected by auger (for disturbed soil sample) and by core sampler (for bulk density). Soil samples were packed in a plastic bowl and transported to a soil testing center for further analysis. In the laboratory samples were labeled, air dried, cleaned from contaminants and plant debris, ground by mortar and pestle, and finally sieved with a $2 \mathrm{~mm}$ sieve for analysis. Analysis of soil samples was carried out at Bako Research Center based on their standard laboratory procedures.

\subsection{Soil lab analysis}


After soil samples were well prepared, bulk density was determined by dividing dry soil by its volume after drying to constant weight at $105^{\circ} \mathrm{C}$. The $\mathrm{pH}$ was determined by potentiometrically on soil: water suspensions (soil: water ratio 1:2.5 (Guittan and Carballas 1976). The cation exchange capacity (CEC) was determined by $\mathrm{NH} 4 \mathrm{Ac}$ extraction followed by $\mathrm{H} 2 \mathrm{SO} 4$ titration at pH 7 (Chapman 1965). The exchangeable $\mathrm{Ca}$, and $\mathrm{Mg}$, by NH4 acetate extraction followed by EDTA titration. Exchangeable $\mathrm{K}$ was determined by NH4Ac extraction followed by a flame photometer (Jackson 1970). Soil texture was analyzed by the hydrometer method (Bouyoucos 1962). Soil moisture content was determined by the gravimetric method (Black 1965). Total N was determined by Kejeldhai (Bremner 1996). The percent of organic carbon was analyzed by wet oxidation with dichromate (Walklay and Black 1934). Available Pwas determined by Bray II,1945 as the soil is acidic.

\subsection{Estimation of soil organic carbon stocks}

Soil organic carbon Stock was estimated up to the depth of $40 \mathrm{~cm}$. The soil organic carbon stock was calculated according to Were et.al. (2015) as indicated in the following equation:

SOCst $=S O C \% / 100 * B D * D$

Where SOC $=$ Soil organic carbon $(\%)$ of a given soil depth

SOCst $=$ soil organic carbon stock, $\mathrm{Kg} \mathrm{C} \mathrm{ha-1}$

$\mathrm{BD}$ (Bulk density) = soil mass per sample volume $\left(\mathrm{kg} \mathrm{m}^{-3}\right)$;

$\mathrm{D}=$ depth of soil in $\mathrm{m}$

\subsection{Statistical analysis}

The soil property data generated through laboratory analysis were subjected to a two-way analysis of variance (ANOVA) to detect whether differences in soil attributes between the land use and soil depth using the general linear model procedure of the Statistical Analysis System (SAS Institute 2008). The least significant difference (LSD) test was employed for mean separation for the soil properties that were founded to be significantly different in statistical terms.

\section{Results And Discussion}

\subsection{Effect of land-use change on soil organic carbon (SOC) Stock}

The analysis of variance results (Table 1$)$ indicated that the SOC stock was significantly $(p<0.05)$ affected by land-use types and by soil depth. The mean value of carbon stock under cultivated land, forest land, and grazing land at the depth of $0-20 \mathrm{~cm}$ were 43.09 tone $\mathrm{ha}^{-1}, 81.86$ tone ha $^{-1}$, and 57.71 
tone $\mathrm{ha}^{-1}$ respectively, whereas, at depth of $20-40 \mathrm{~cm}$ the value of SOC stock under cultivated soil, forest soil and grazing soil were 38.08 tone ha-1, 70.31 tone $\mathrm{ha}^{-1}$ and 44.54 tone ha-1 respectively.

Forest land had the highest SOC stock and cultivated land had the lowest value. Next to the forest, grazing land had the highest SOC stock. Organic matter input and turnover rates are the drivers for the soils carbon stock. tree species strongly influence the forest floor in terms of carbon stock (Jandl et al. 2007a). The declination of SOC stock in cultivated land could be due to vegetation loss and unsustainable soil management. The present finding agreed with (Jordan et al. 2010; Moscatelli et al. 2007) who reported that the SOC loss in cultivated soil could be due to reduced OM input, as well as due to reduced physical protection of soil from erosion and the increased decomposition rate as a consequence of tillage.

Numerous studies reported decreasing soil organic carbon stocks after a land-use change from natural or semi-natural ecosystems (forest land and grassland) to cropland and a cultivation induced soil organic carbon decline of about $20-60 \%$ when forest land and grassland were converted to cropland (Guo and Gifford 2002; Murfy et al. 2002; Poeplau et al. 2011; Wiesmeier et al. 2012, 2015; Oberholzer et al. 2014). The carbon stocks increased by $20-50 \%$ after land-use changes from cropland to grassland or forest land (Guo and Gifford, 2002). The mean value of SOC stock of all land uses decreased significantly as depth increase, which agrees with the findings of Diekow et al. (2005).

Table 1

Soil organic stock under the different land uses

\begin{tabular}{|llll|}
\hline \multicolumn{3}{|l|}{ Soil depth (0-20cm) } \\
\hline Land use & BD & $\%$ SOC & SOC stock (tone ha ${ }^{-1}$ ) \\
\hline Farm land & $1.62^{\mathrm{a}}$ & $1.33^{\mathrm{a}}$ & $43.09^{\mathrm{a}}$ \\
\hline Forest land & $1.08^{\mathrm{c}}$ & $3.79^{\mathrm{c}}$ & $81.86^{\mathrm{b}}$ \\
\hline Grazingland & $1.63^{\mathrm{a}}$ & $2.29^{\mathrm{d}}$ & $57.71^{\mathrm{c}}$ \\
\hline Soil depth $(20-40 \mathrm{~cm})$ & & \\
\hline Farm land & $1.60^{\mathrm{a}}$ & $1.19^{\mathrm{b}}$ & $38.08^{\mathrm{a}}$ \\
\hline Forest land & $1.26^{\mathrm{b}}$ & $2.79^{\mathrm{d}}$ & $70.31^{\mathrm{c}}$ \\
\hline Grazing land & $1.31^{\mathrm{b}}$ & $1.70^{\mathrm{ab}}$ & $44.54^{\mathrm{d}}$ \\
\hline $\mathrm{p}(0.05)$ & 0.07 & 0.04 & 0.01 \\
\hline
\end{tabular}

3.2. Effect of land-use change on selected soil properties 3.2.1. Soil Physical properties 


\section{Soil texture}

As the result in Table 2 revealed, the mean value of the percentage of sand in cultivated land was $61 \%$ and that of forest land was found to be $52 \%$ at depth of $0-20 \mathrm{~cm}$. The highest percent of sand was found in cultivated while the lowest was found in grazing land (50\%). While, at the depth of $20-40 \mathrm{~cm}$ the percent of sand under cultivated was $58 \%$, forestland $(45 \%)$, and that of grazing lands was $54 \%$.

The mean values of silt at depth of $0-20 \mathrm{~cm}$ under cultivated, grazing, and forest lands were $33.5 \%, 38 \%$, and $43.5 \%$ respectively. While, at the depth of $20-40 \mathrm{~cm}$ it was $30.5 \%, 37 \%$, and $44 \%$ respectively. The percentage value of clay soil at depth of $0-20 \mathrm{~cm}$ under cultivated, grazing, and forest lands were $5.5 \%$, $10 \%$, and $6.5 \%$ respectively. While, at depth of $20-40 \mathrm{~cm}$, the clay content under cultivated, grazing, and forest lands was $11.5 \%, 9 \%$, and $11 \%$ respectively. The textural class for cultivated land at depth of 0 $20 \mathrm{~cm}$ and $20-40 \mathrm{~cm}$ were sandy clay loam and sandy loam respectively. For grazing land, the textural class at both depths $(0-20$ and $20-40 \mathrm{~cm})$ was loam soil. The textural class at depth of $0-20$ and 20 $40 \mathrm{~cm}$ was sandy loam. Unlike sandy soil, clay soil was higher in forest land than both cultivated and grazing lands. Despite, slightly the higher silt content was observed in grazing land and the lower was in cultivated land which agrees with research Lechisa et al. (2014) who reported that the highest silt content was observed forest land and the lower was in cultivated land.

In this finding, the highest sand contents (61\%) in the cultivated land was in contrast to the result of Mesgistu et al. (2017) who said that the highest sand and silt were found in forest land in Warandhab area, Horo Guduru Wollega Zone, Oromia, Ethiopia. However, the highest silt contents (44\%) at the depth of $20-40 \mathrm{~cm}$ in forest soil land agrees with this finding. The highest sand content in cultivated land is perhaps due to a high amount of rainfall in the area that washed away the finer soil particles (clay) leaving behind the sand fractions (Getahun et al. 2016).

Table 2

Textural Class of the land-uses

\begin{tabular}{|llllll|}
\hline Land Use & Depth $(\mathbf{c m})$ & \% Sand & \% Silt & \% Clay & Textural class \\
\hline Cultivated land & $0-20$ & 61 & 33.5 & 5.5 & Sandy clay loam \\
\hline Grazing land & $0-20$ & 52 & 38 & 10 & Sandy loam \\
\hline Forest land & $0-40$ & 58 & 30.5 & 11.5 & Sandy loam \\
\hline & $20-40$ & 54 & 37 & 9 & Sandy loam \\
\hline Bulk Density & & 50 & 43.5 & 6.5 & Loam soil \\
\hline
\end{tabular}

As indicated in Table 2, the bulk density (BD) values were slightly different for the land use types. The mean value of BD under forest, cultivated and grazing land at the depth of $0-20 \mathrm{~cm}$ were $1.08 \mathrm{~g} \mathrm{~cm}^{-3}$, 


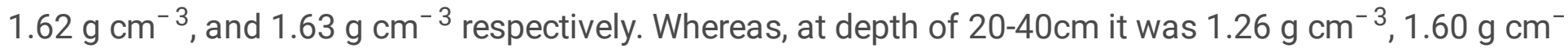
3 , and $1.31 \mathrm{~g} \mathrm{~cm}^{-3}$ respectively. Comparatively cultivated land had significantly $(p<0.05)$ higher $(1.62 \mathrm{~g}$ $\mathrm{cm}^{-3}$ ) BD at depth of $0-20 \mathrm{~cm}$. This is might be due to the compaction of the topsoil by cultivation or due to low organic matter. While forest land had the lowest $\left(1.08 \mathrm{~g} \mathrm{~cm}^{-3}\right)$ bulk density which could be due to the presence of high organic matter. An increase in root penetration and biological activity might have decreased bulk density in forest soils. The result indicated that surface soil had significantly lower bulk density than subsurface soil. This could be due to the presence of higher organic matter in surface soil (Table 3). This agreed with the findings of Terefe et al. (2020) where the topsoil had less BD than the subsurface soil. This could also be due to overgrazing of the grazing land and the use of machinery or intensive agricultural practices in the cultivated land.

\section{Soil Moisture}

The moisture content $(\%)$ of the surface soils $(0-20 \mathrm{~cm})$ of the study area is shown in Table 3 . Accordingly, forest land, cultivated land, and grazing land have the mean value $20.6 \%, 10.84 \%$, and $14.76 \%$ respectively and at the depth of $20-40 \mathrm{~cm}$, the mean value of moisture in forest land, cultivated land, and grazing land were $25.85 \%, 10.86 \%$ and $15.12 \%$ respectively. The surface $(0-20 \mathrm{~cm})$ soil had lower moisture content than that of the lower depth $(20-40 \mathrm{~cm})$. This is might be due to solar heating at topsoil than the subsurface soil. Forest land had significantly higher moisture content, whereas cultivated land had the lowest moisture content; this implies that the soil under forest was covered by vegetation which results in low evaporation; water stays in the soil. This result agreed with (Duiker and Lal 2000; Post and Kwon 2000; Knowles and Singh, 2003; Baker, 2007) who reported soil protected by the superficial layer of organic matter improves the capture and the use of rainfall through increased water absorption and infiltration and decreased evaporation from the soil surface. This leads to reduced runoff and soil erosion with higher soil moisture throughout the season compared to the disturbed soils left unprotected (Bationo et al. 2007). 
Table 3

Effects of land-use change on soil bulk density and soil moisture

\begin{tabular}{|lllll|}
\hline Land uses & Depth $(\mathbf{c m})$ & $\mathrm{BD}\left(\mathrm{g} / \mathrm{cm}^{3}\right)$ & Moisture (\%) \\
\hline Cultivated land & $0-20$ & $1.62^{\mathrm{ab}}$ & $10.84^{\mathrm{e}}$ \\
& $20-40$ & $1.60^{\mathrm{b}}$ & $10.86^{\mathrm{e}}$ \\
\hline Grazing land & $0-20$ & $1.63^{\mathrm{a}}$ & $14.76 \mathrm{~d}$ \\
& $20-40$ & $1.31^{\mathrm{c}}$ & $15.12^{\mathrm{c}}$ \\
\hline Forest land & $0-20$ & $1.08^{\mathrm{e}}$ & $20.6^{\mathrm{b}}$ \\
& $20-40$ & $1.26^{\mathrm{d}}$ & $25.85^{\mathrm{a}}$ \\
\hline $\mathrm{p}(0.05)$ & & 0.02 & 0.01 \\
\hline
\end{tabular}

\subsection{Soil Chemical properties}

\section{Soil pH}

Soil pH was found to be significantly $(\mathrm{p}<0.05)$ affected by land-use change and soil depth. Forest soil has the highest mean value of $\mathrm{pH}(6.20)$ at the depth of $20-40 \mathrm{~cm}$, whereas it was significantly lower (4.63) in cultivated lands at the depth of $0-20 \mathrm{~cm}$. The lower $\mathrm{pH}$ at the cultivated land when compared with forest land and grazing lands implies that the depletion of basic cations in crop harvest and the continuous use of ammonium-based fertilizers such as diammonium phosphate $\left(\mathrm{NH}_{4}\right)_{2} \mathrm{HPO}_{4}$ in cultivated lands make the soil acidic. The oxidation of these fertilizers by soil micro-organisms produce inorganic acids. This acid releases $\mathrm{H}^{+}$to the soil solution that in turn lowers the $\mathrm{pH}$ of the soil. In general, as the depth increase, the $\mathrm{pH}$ value decrease (acidity increase). This is because of the larger organic matter content observed in the surface soils across the land uses and the humified organic matter can bind tightly with $\mathrm{Al}^{3+}$ and reduces their activity in the soil solution which raises the soil $\mathrm{pH}$. The present study agreed with (Ristow et al. 2010) who reported as the soil pH decreases, most desirable crop nutrients become less available while others, often undesirable, become more available and can reach toxic levels. The basic cations such as $\mathrm{Ca}^{2+}$ and $\mathrm{Mg}^{2+}$ also have shown a decreasing trend with increasing depth. The adsorption of these cations on the colloidal complex gives replacement of $\mathrm{H}^{+}$and $\mathrm{Al}^{+3}$ which lowers the percentage of acid saturation which increases the soil $\mathrm{pH}$.

\section{Soil Organic Carbon}

As presented in (Table 4), soil organic carbon (SOC) was significantly $(p<0.05)$ affected by land-use change and soil depth. In both soil depths $(0-20 \mathrm{~cm}$ and $20-40 \mathrm{~cm})$, SOC was lower in cultivated fields as compared to other land uses. The analysis of the effect of soil depth showed the highest SOC $(3.79 \%)$ under forest soils at $0-20 \mathrm{~cm}$, While the lowest SOC $(1.19 \%)$ was recorded in cultivated soils at the depth 
of $20-40 \mathrm{~cm}$. This agreed with Lal (2002) and Mengistu and Fassil (2010) who reported that soil organic carbon storage and soil nutrient availability are greater in forest land than in the cropland and pastures that replace them. Extensive deforestation and the conversion of natural forests into agricultural lands in the Ethiopia ecosystem led to a significant decline in organic matter levels. Woldeamlak and Stroonsnigder (2003) reported the conversion of forest land into grazing land and cultivated land led to a large decrease of organic matter at Chemo Watershed Ethiopia. Most cultivated soils of Ethiopia are poor in organic matter contents due to the low amount of organic materials applied to the soil and complete removal of the biomass from the field (Yihenew 2002), and due to steep relief condition, intensive cultivation, and excessive erosion hazards (Nyssen et al. 2004). In agreement with this, all agricultural fields in the study area had low organic carbon content according to the classification presented in Landon (1984). Tekalign (1991) also stated that an organic matter content of less than two (2\%) as an indication of soil degradation for tropical soils involving a high risk of soil erosion.

\section{Total nitrogen}

The result presented in (Table 4) showed there were significant $(p<0.05)$ variations in total nitrogen among the land uses and soil depth. The mean value of total nitrogen at the depth of $0-20 \mathrm{~cm}$ for cultivated land, forest land, and grazing land was $0.11 \%, 0.33 \%$, and $0.20 \%$ respectively. While, at the depth of $20-40 \mathrm{~cm}$ it is $0.10 \%, 0.27 \%$ and $0.15 \%$ respectively. Total nitrogen increased in the order of cultivated land < grazing land < forest land in the study area. The present finding agreed with (Nega 2006), who reported that the average total Nitrogen $(\mathrm{N})$ increased from cultivated to grazing and forest land soils, which again declined with increasing depth from surface to subsurface soils. Since forest land had higher OM, higher TN was recorded in forest land than cultivated and grazing lands at both depths (Table 4). This agreed with the findings of Hazelton et al. (2007) where the total nitrogen was measured higher in soils with high organic matter.

Generally, cultivated soils had significantly lower TN at all depth as compared to grasslands and forest lands, which indicated continuous cultivation, ultimately reduced the total nitrogen contents in the soil. Due to land-use shifts from forest land to cultivated land, the TN content was declined, and also it was declined with increasing soil depth. This finding agreed with the findings of Nega (2006) in Senbat subwatershed, western Ethiopia, where average TN increased from cultivated to grazing and forest soils. The minimum change of TN under cultivated land compared to forestland and grazing land shows that fertilizer applications may not have replaced the total $\mathrm{N}$ lost due to harvest removal, leaching, and humus losses associated with cultivation (Eyayu et al. 2009).

According to Malo et al. (2005), the lower level of nitrogen in cultivated fields compared to other land use implied that fertilizer additions have not replaced the TN lost due to harvest removal, leaching, and humus losses associated with cultivation. The continuous cultivation could have also aggravated OC oxidation and loss of $\mathrm{N}$ in cultivated fields resulting in the lowest contents.

\section{Available Phosphorus}


As shown in Table 4, the available P content $\left(\mathrm{mg} \mathrm{kg}^{-1}\right)$ of the surface soils $(0-20 \mathrm{~cm})$ in forest soil, cultivated soil, and grazing soil had the mean value $27.83,12.63$, and 4.17 respectively and at the depth of $20-40 \mathrm{~cm}$ the mean value of available $P$ in forest soil, cultivated soil and grazing land soil is 24.53 , 10.43 and 2.43 respectively. The surface $(0-20 \mathrm{~cm})$ soil has significantly $(p<0.05)$ higher available $P$ content than that of the lower depth. The available $P$ content of soils significantly declined due to the conversion of natural forests into grazing lands and farmland. The high content of available $P$ in the forest land could be due to the high content of soil OM resulting in the release of organic phosphorous thereby enhance available P under forest land. Similarly, this result is in agreement with the findings of Abad et al. (2014) who reported that the available $P$ was high in forest land as compared to pasture land and cultivated land at $0-30 \mathrm{~cm}$ soil depth.

The higher available P content at both depths under forest land is likely the consequences of the long term litter accumulation and the associated increase in microbial activity. The results were in agreement with those of Materechera and Mkhabela (2001) who reported that organic matter influence P in soil solution by complexing $\mathrm{P}$ from the adsorption site in ligand exchange and increase the mobility of inorganic $P$, particularly in acid soils, by decreasing the chemical activity of iron and aluminum. The lack of available $\mathrm{P}$ in the soils limits the growth of plants. Cultivated land should be supplied with inorganic fertilizer to increase the concentration of $\mathrm{P}$ in the soil solution that is required by crops. Phosphorus is involved in several key plant functions, including energy transfer (Uchida 2000).

High availability of $P$ existed in forest land and the lowest was in cultivated land. This is might be the pool of available P could be trees in the forest land with abundant microorganisms that return via litterfall to the soil (Asmamaw and Mohammed 2013). In agricultural land, available phosphorus (P) was reduced most probably due to a decline in both \% SOC, CEC, and soil acidification (Achalu et al. 2012; Nisar et al. 2013). This finding also agrees with the result of Birhanu et al. (2016) who reported alteration of forest land to agricultural land decreased the availability of phosphorus in western Ethiopia.

In contrast to this finding, Mengistu et al. (2017) found higher available P in the soil of cultivated land as the result of crop residue left on cultivated land and later plowed in properly. In forests land, fallen vegetation cover and natural pruning of tree take time to return into the soil to decompose and increase SOM content, which lead to increases available Phosphorous content. Consequently, available P content was significantly $(P<0.05)$ different among different land-use systems (Alemayehu and Beyene 2013).

\section{Exchangeable Cations (Ex.K, Ca and Mg)}

The exchangeable K of soil under study area was significantly $(p<0.05)$ affected by land use type and depth of the soil (Table 4). Exchangeable $K$ content at the depth of $0-20 \mathrm{~cm}$ in forest land, cultivated land, and grazing land was $1.51 \mathrm{cmol}(+) \mathrm{Kg}^{-1}, 1.04 \mathrm{cmol}(+) \mathrm{Kg}^{-1}$, and $1.13 \mathrm{cmol}(+) \mathrm{Kg}^{-1}$ respectively. At the depth of $20-40 \mathrm{~cm}$, Exchangeable $\mathrm{K}$ of forest land, cultivated land, and grazing land were $0.79,0.88$, and $0.44 \mathrm{cmol}(+) \mathrm{Kg}^{-1}$ respectively. Soils of forest land had the highest exchangeable $\mathrm{K}\left(1.51 \mathrm{cmol}(+) \mathrm{Kg}^{-1}\right)$ content than soils of cultivated and grazing lands at the surface soil (depth of $0-20 \mathrm{~cm}$ ) and 
exchangeable $\mathrm{K}$ content of the soil declined with increase in depth. This result is supported by previous findings that indicate the intensity of cultivation, and the use of acid-forming inorganic fertilizers affect the distribution of $\mathrm{K}$ in the soil system and enhance its depletion (Malo et al. 2005). Similarly, Yitbarek et al. (2013) reported that the exchangeable $\mathrm{K}$ of soil is higher in forest land than cultivated and grazing lands.

The analysis of variance results indicated that the exchangeable Ca was significantly $(p<0.05)$ affected by land-use types and soil depth. The presence of such significant variation on exchangeable Ca could be due to different management practices. At the depth of $0-20 \mathrm{~cm}$, the mean values of exchangeable $\mathrm{Ca}$ under forest, cultivated and grazing lands were $23.30 \mathrm{cmol}(+) \mathrm{Kg}^{-1}, 9.27 \mathrm{cmol}(+) \mathrm{Kg}^{-1}$, and $14.43 \mathrm{cmol}$ $(+) \mathrm{Kg}^{-1}$ respectively. However, at the depth of $20-40 \mathrm{~cm}$ its mean value under forest, cultivated and grazing lands was $12.27 \mathrm{Cmol}(+) \mathrm{Kg}^{-1}, 6.87 \mathrm{cmol}(+) \mathrm{Kg}^{-1}$, and $8.17 \mathrm{cmol}(+) \mathrm{Kg}^{-1}$ respectively. This implies that the exchangeable Ca was higher at the surface soil depth than that of the subsurface soil depth. This could be due to the abundance of animal and plant residues at the surface layer of soil than the subsurface soil layer. This is agreed with the findings of Alemayehu and Beyene (2013) who in their results revealed that the exchangeable Ca content of the soil was higher on the surface soil layer than the subsurface soil layer due to the association of biological activity and accumulation from plant residues. In contrast, Bore and Bedadi (2015) reported that the exchangeable Ca was increasing with increasing soil depth since it is susceptible and the possibility of easily leach downward by runoff and water percolation.

The analysis of variance results indicated the exchangeable Mg was significantly $(p<0.05)$ affected by land-use types and by soil depth. The exchangeable $\mathrm{Mg}$ concentrations followed a similar trend as that of $\mathrm{Ca}$ under the land uses. The mean value of exchangeable $\mathrm{Mg}$ at depth of $0-20 \mathrm{~cm}$ under forest, cultivated, and grazing land uses were $12.70,5.83$, and $6.77 \mathrm{cmol}(+) \mathrm{Kg}^{-1}$ respectively. While, at the depth of 20$40 \mathrm{~cm}$, the mean values of exchangeable $\mathrm{Mg}$ in forest land, cultivated land, and grazing land were 5.47, 4.20 , and $5.83 \mathrm{cmol}(+) \mathrm{Kg}^{-1}$ respectively. The highest and lower values of exchangeable $\mathrm{Mg}$ were found under grazing land and cultivated land respectively. The low exchangeable $\mathrm{Ca}$ and $\mathrm{Mg}$ under cultivated land might be due to leaching, soil erosion, and crop harvest as it was reported by Negassa (2001).

\section{Cation Exchanging Capacity (CEC)}

The analysis of variance results (Table 4$)$ revealed that the CEC of the soils was significantly $(p<0.05)$ affected by the land-use change and the depth of the soil. The mean value of CEC under forest land, cultivated land, and grazing land at the depth of $0-20 \mathrm{~cm}$ were $37.55,25.20$, and $27.31 \mathrm{cmol}(+) \mathrm{Kg}^{-1}$ respectively. For the depth of $20-40 \mathrm{~cm}$, the mean values of forest land, cultivated land, and grazing land were $24.10,24.04$, and $23.86 \mathrm{cmol}(+) \mathrm{Kg}^{-1}$ respectively (Table 4). This implies that the highest CEC value was found in the surface soil layer than subsurface. The significantly higher CEC in forest land might be due to the presence of higher soil organic matter. This result is in line with the findings of Yitbarek et al. (2013) who reported that the CEC of soil was higher in forest land compared to that of the adjacent cultivated and grazing lands in Abobo area, Western Ethiopia. This depletion of OC in farmland could be 
due to intensive cultivation. These results were also in agreement with the findings of Boke (2004) in Kembata-Tembaro southern Ethiopia and Negassa (2001) in Bako area, western Ethiopia

The CEC values of the soil decreased with depth consistently from forest land to cultivated land.

Similarly, Nigussie et al. (2012) reported that the CEC of soil was higher in the subsurface of the soil layer under the adjacent forest, cultivated and grazing lands. But the result of the present study is unparalleled of the findings of Alemayehu and Beyene (2013) who reported that the CEC of the soil was not significantly affected by soil depth at the depth of $0-15 \mathrm{~cm}$ and $15-30 \mathrm{~cm}$ under adjacent maize, Enset and grasslands in Southern Ethiopia.

Table 4

Effects of land-use change on soil chemical properties

\begin{tabular}{|c|c|c|c|c|c|c|c|c|}
\hline \multicolumn{9}{|c|}{ Soil depth $(0-20 \mathrm{~cm})$} \\
\hline Land use & $\mathrm{pH}$ & $\%$ SOC & $\% \mathrm{TN}$ & AvP & Ex.Ca & Ex.Mg & Ex.K & CEC \\
\hline Farm land & $4.63^{c}$ & $1.33^{\mathrm{e}}$ & $0.11^{\mathrm{e}}$ & $12.63^{c}$ & $9.27^{d}$ & $5.83^{c}$ & $1.13^{b}$ & $25.20^{\mathrm{b}}$ \\
\hline Forest land & $6.02^{\mathrm{a}}$ & $3.79^{a}$ & $0.35^{\mathrm{a}}$ & $27.83^{a}$ & $23.30^{\mathrm{a}}$ & $12.70^{\mathrm{a}}$ & $1.51^{\mathrm{a}}$ & $37.55^{\mathrm{a}}$ \\
\hline Grazing land & $5.14^{\mathrm{b}}$ & $2.29^{c}$ & $0.20^{c}$ & $4.17^{e}$ & $14.43^{b}$ & $6.77^{b}$ & $1.04^{\mathrm{b}}$ & $27.31^{c}$ \\
\hline \multicolumn{9}{|c|}{ Soil depth $(20-40 \mathrm{~cm})$} \\
\hline Farm land & $5.20^{\mathrm{b}}$ & $1.19^{f}$ & $0.10^{f}$ & $10.43^{d}$ & $6.87^{\mathrm{e}}$ & $4.20^{\mathrm{a}}$ & $0.88^{\mathrm{cd}}$ & $24.04^{b}$ \\
\hline Forest land & $6.02^{\mathrm{a}}$ & $3.10^{a}$ & $0.28^{b}$ & $24.52^{b}$ & $12.27^{c}$ & $6.17^{b}$ & $0.79^{c}$ & $24.10^{c}$ \\
\hline Grazing land & $5.13^{b}$ & $1.70^{\mathrm{d}}$ & $0.15^{d}$ & $2.43^{f}$ & $8.17^{a}$ & $5.47^{a}$ & $0.44^{\mathrm{e}}$ & $23.86^{b}$ \\
\hline$p(0.05)$ & 0.03 & 0.05 & 0.01 & 0.05 & 0.02 & 0.04 & 0.016 & 0.045 \\
\hline
\end{tabular}

\section{Conclusion}

Land-use change is one of the important factors influencing the soil properties and exerts the most significant effects on the soil. Changes in land use and management can have profound effects on the quantity and dynamics of soil organic matter and in turn, on the soil ecosystem functions. Soil organic carbon stocks, the physical and chemical properties of land uses in the study area were affected by landuse systems and depth. Soil organic carbon stock and most of the physical and chemical properties including $\mathrm{P}, \mathrm{CEC}, \mathrm{K}, \mathrm{N}$ were significantly higher in the forest as compared to grazing land and cultivated land. While, $\mathrm{pH}$ and bulk density were lower in forest land as compared to cultivated and grazing lands. Thus, maintaining forest land, reducing the intensity of cultivation, and adopting integrated soil fertility management must be undertaken in the area for improving soil organic carbon stock and soil properties.

\section{Declarations}


Acknowledgements

The authors are grateful to Wollega University for material and laboratory support

\section{Authors' contributions}

MW interpreted the data and wrote the manuscript. DW collected, analyzed data. GK edited, commented, and suggested ideas in the manuscript preparation process. All authors approved the final manuscript.

\section{Funding}

Not applicable

\section{Consent for publication}

Not applicable

\section{Availability of data and materials}

Data are available from the corresponding author upon request

\section{Declarations}

Ethics approval and consent to participate

Not applicable.

\section{Conflict of interest}

The authors declare no conflict of interest

\section{References}

1. Abad JRS, Khosravi H, Alamdarlou EH (2014) Assessment of the effects of land-use changes on soil physicochemical properties in Jafarabad of Golestan Province, Iran. Bulletin of Environment, Pharmacology and Life Sciences, 3(3): 296-300

2. Achalu C, Heluf, Gebrekidan, Kibebew, Kibret, and Tadesse A (2012) Effects of Liming on AcidityRelated Chemical Properties of Soils of Different Land Use Systems in Western Oromia, Ethiopia. World Journal of Agricultural Sciences,8, No.6: 560-567

3. Alemayehu K, Beyene S (2013) Effects of different land use systems on selected soil properties in South Ethiopia. Journal of Soil Science Environmental ManagementVol 4(5):100-107

4. Alemayehu K, Sheleme B (2013) Effects of different land-use systems on selected soil properties in South Ethiopia. Journal of soil science and Environmental Management, Soil Science Department, Hawassa University, Ethiopia 
5. Anikwe M (2010) Carbon storage in soils of Southeastern Nigeria under different management practices. Carbon Balance Manag 5(1):5

6. Asmamaw LB, Mohammed AA (2013) Effects of slope gradient and changes in land use/cover on selected soil physicobiochemical properties of the Gerado catchment, north-eastern Ethiopia. Int J Environ Stud 70(1):111-125. DOI:10.1080/00207233.2012.751167

7. Baker JM, Ochsner TE, Venterea RT, Griffis TJ (2007) Tillage and soil carbon sequestration What do we really know? Agriculture Ecosystems and Environment, 118, 1-5

8. Birhanu I, Mohammed M, Kibret K (2016) Impact of deforestation and subsequent cultivation on soil fertility in Komto, Western Ethiopia. Journal of Soil Science and Environmental Management. Vol. 7(12), pp. 212-221 December 2016 DOI: 10.5897/JSSEM2016.0578

9. Black CA (1965b) Physical and mineralogical properties, Methods of Soil Analysis: Part I. American Society of Agronomy, Madison

10. Boke S (2004) Soil P fractions as influenced by different land-use systems in Andosols and Nitosol in Kembata-Tembaro and Welayta zone.SNNPRS. MSc Thesis Alemaya University.p.131

11. Bore G, Bedadi B (2016) Impacts of Land Use Types on Selected Soil Physico-Chemical Properties of Loma Woreda, Dawuro Zone, Southern Ethiopia. Science Technology Arts Research Journal 4(4):40

12. Bouyoucos GJ (1962) Hydrometer method improved for making particle size analyses of soil. Agron J 53:464-465

13. Bremner J (1996) Nitrogen-total. In: Sparks D, Page A, Helmke P, Loeppert R, Soltanpour P, Tabatabai M, Johnston C, Sumner M (eds) Methods of soil analysis. Part 3-Chemical methods. Soil Science Society of America USA, pp 1085-1121

14. Cary NC USA

15. Chapman HD (1965) Cation exchange capacity by ammonium saturation: Methods of soil analysis, Part 2. American Society of Agronomy, Wisconsin, USA, Madison

16. Eaton JM, McGoff NM, Byrne KA, Leahy,p., and Kiely G (2008) Land cover change and soil organic carbon stocks in the Republic of Ireland 1851-2000

17. Eyayu M, Heluf G, Mamo T, Assen M (2009) Effects of land-use change on selected soil properties in the Tara Gedam Catchment and adjacent agroecosystems, north-west Ethiopia, Ethiopian. Journal of Natural Resources 11(1): 35-62

18. FAO (2008) Global Review of Good Agricultural Extension and Advisory Service practices Rome. Italy $16: 152$

19. Getahun K, Heluf G, Alamrew T, Olumana M, Hans Hurni (2016) Land-use changes induced by irrigation development in the Fincha'a sugar estate, Blue Nile basin, Ethiopia. Journal of Biodiversity Environmental Sciences 3:No.11: 31-47

20. Guo LB, Gifford M (2002) Soil carbon stocks and land-use change: A meta Haru, A. and Ethiopia W 2012. Influences of inoculation methods and phosphorus levels on nitrogen fixation attributes and 
yield of soybean (Glycine max L.). American Journal of Plant Nutrition and Fertilization Technology, 2(2): 45-55

21. Hailu T, Mekuria A, Tamene L, Kindu, Mekonnen J Recha and Solomon D (2020) Effects of sustainable land management interventions on selected soil properties in Geda watershed, central highlands of Ethiopia. Ecological Processes 9:14. https://doi.org/10.1186/s13717-020-0216-2

22. Hazelton P, Murphy B (2007) Interpreting soil test results: what do all those numbers mean? CSIRO. Department of Natural Resources

23. Heluf G, Wakene N (2006) Impact of land use and management practices on chemical properties of some soils of Bako areas, western Ethiopia. Ethiopian Journal of Natural Resources 8:No.2: 177-197

24. IPCC (2001) Climate change. The Third Assessment Report of the Intergovernmental Panel on Climate Change. Cambridge University Press, UK

25. Islam KR, Weil RR (2000) Land-use effects on soil quality in a tropical forest ecosystem of Bangladesh. Agriculture Ecosystems Environment 79:9-16

26. Izaurralde RC, Rosenberg NJ, Lal R (2001) Mitigation of climatic change by soil: Carbon sequestration Issues of science, monitoring, and degraded lands. Adv Agron 70:1-75

27. Jandl R, Lindner M, Vesterdal L, Bauwens B, Baritz R, Hagedorn F, Johnson DW, Minkkinen K, Byrne KA (2007a) How strongly can forest management influence soil carbon sequestration? Geoderma, 137: 253-268

28. John B, Yamashita T, Ludwig B, Flessa H (2005) Storage of organic carbon in aggregate and density fractions of silty soils under different types of land use. Geoderma 128:63-79

29. Lal R (2002b)Soil Carbon dynamics in cropland and rangeland. Environmental pollution.116.pp 353-362

30. Lalisa AD, Peter AM, Meine VN (2014) Climate Change Mitigation and Adaptation in the Land Use Sector: From Complementarity to Synergy. Environmental Management. DOI 10.1007/s00267-0140331-x

31. Landon J (1984) Booker tropical soil manual: A handbook for soil survey and agricultural land evaluation in the tropics and subtropics. John Wiley and Sons, New York

32. Lechisa,Takele, Achalu, Chimdi A, Abebaw (2014) Dynamics of soil fertility as influenced by different land-use systems and soil depth in west Showa zone, Gindeberet district, Ethiopia. Agriculture Forestry Fisheries 3:No.6: 489-494

33. Liu ZP, Shao MB, Wang YQB (2012) Large-scale spatial variability and distribution of soil organic carbon across the entire Loess Plateau. China. Soil Res 50:114-124

34. Malo DD, Schumacher TE, Doolittle JJ (2005) Long-term cultivation impacts on selected soil properties in the northern Great Plains. 81, 277-291. https://doi.org/10.1016/j.still.2004.09.015

35. Malo DD, Schumacher TE, Doolittle JJ (2005) Long-term cultivation impacts on selected soil properties in the northern Great Plains. Soil \& Tillage Research, 277-291 
36. Materechera SA, Mkhabela TS (2001) Influence of Land-Use on Properties of a Ferralitic Soil Under Low External Input Farming in Southeastern Swaziland. Soil Tillage Research 65:15-25

37. McCarl BA, Schneider UA (2001) - Climate change -Greenhouse gas mitigation in US agriculture and forestry. Science 294:2481-2482

38. Mengistu C, Kibret K, Fite T (2017) Influence of different land-use types and soil depths on selected soil properties related to Soil fertility in warandhab area, Horo Guduru Wollaga zone, Oromiya, Ethiopia. International journal of environmental science natural resource 4:2572-1119

39. Murty D, Kirschbaum MUF, Mc.Murtrie RE, McGifvary H (2002) Does the conversion of forest to agricultural land change soil carbon and nitrogen? A review of the literature. Glob Change Biol $8: 105-123$

40. Nega E (2006) Land-use changes and their effects on physical and chemical properties. Senbat subwatershed, western Ethiopia. MSc Thesis Submitted to School of Graduate Studies, Alemaya University, Ethiopia. p72

41. Negassa W (2001) Assessment of important physicochemical properties of Nitosols under different management systems in Bako area, western Ethiopia. A thesis submitted to School of Graduate Studies, Alemaya University, Ethiopia. 93p

42. Nigussie A, Kissi E, Ambaw G (2012) Effect of Biochar Application on Soil Properties and Nutrient Uptake of Lettuces (Lactuca sativa) Grown in Chromium Polluted Soils. American-Eurasian J Agric Environ Sci 12(3):369-376

43. Nisar A, Bhat S, lqbal, Sharma SK (2013) Nutrient Status in Relation to Organic Farming Practices: A Review. International Journal of Research and Review, Vol.4; Issue: 8

44. Nyssen J, Poesen J, Moeyersons J, Deckers J, Haile M, Lang A (2004) A Human impact on the environment in the Ethiopian and Eritrean highlands, a state of the art. Earth Sci Rev 64:273-320

45. Oberholzer HR, Leifeld J, Mayer J (2014) Changes in soil carbon and crop yield over 60 years in the Zurich Organic Fertilization Experiment, following land-use change from grassland to cropland. $J$ Plant Nutr Soil Sci 177:696-704

46. Poeplau C, Don A, Vesterdal L, Leifeld J, Wesemael B, Schumacher J, Gensior A (2011) Temporal dynamics of soil organic carbon after land-use change in the temperate Zone. Carbon response functions as a model approach. Glob Change Biol 17:2415-2427

47. Post WM, Kwon K, C (2000) Soil carbon sequestration and land-use change: processes and potential. Global change Biol 6:317-327

48. Ristow PL, Foster J, QM, Ketterings (2010) Lime Guidelines for Field Crops; Tutorial Workbook. Department of Animal Science. Cornell University, Ithaca, 47 pages

49. SAS Institute (2008) The SAS system for windows, version 6.12, vol 12. SAS Institute Inc

50. Shiferaw A, Hurni H, Zeleke G (2013) A review on soil carbon sequestration in Ethiopia to mitigate land degradation and climate change. J Environ Earth Sci 3(12):187-200 
51. Tekalign T (1991) Soil, plant, water, fertilizer, animal manure, and compost analysis. Working Document NO 13. International Livestock Research Center for Africa (ILCA), Addis Ababa

52. Teshome Yitbarek KK, Tsehai S Beyene (2013) Impacts of Land Use on Selected Physicochemical Properties of Soils of Abobo Area, Western Ethiopia. Agriculture, Forestry, and Fisheries. 2(5):177183.http://www.sciencepublishinggroup.com/j/aff) doi: 10.11648/j.aff.20130205.11

53. Uchida R (2000) Essential nutrients for plant growth: Nutrient functions and deficiency symptoms. In: Plan nutrient management in Hawaii's soils. College of Tropical Agriculture and Human Resources, University of Hawaii at Manoa, 31-55 pp

54. Walkley A, Black IA (1934) An examination of the Degtjareff method for determining soil organic matter and a proposed modification of the chromic acid titration method. Soil Sci 37:p29-38

55. Wiesmeier M, Spörlein P, Geuß U, Hangen E, Haug S, Reischl A, Schilling B, von Lützow, KögelKnabner I (2012) Soil organic carbon stocks in southeast Germany (Bavaria) as affected by land use, soil type and sampling depth. Glob Change Biol 18:2233-2245

56. Woldeamlak B, Stroosnijder L (2003) Effects of agro-ecological land-use succession on soil properties in the Chemoga watershed, Blue Nile basin. Ethiopia Geoderma 111:85-98

\section{Figures}




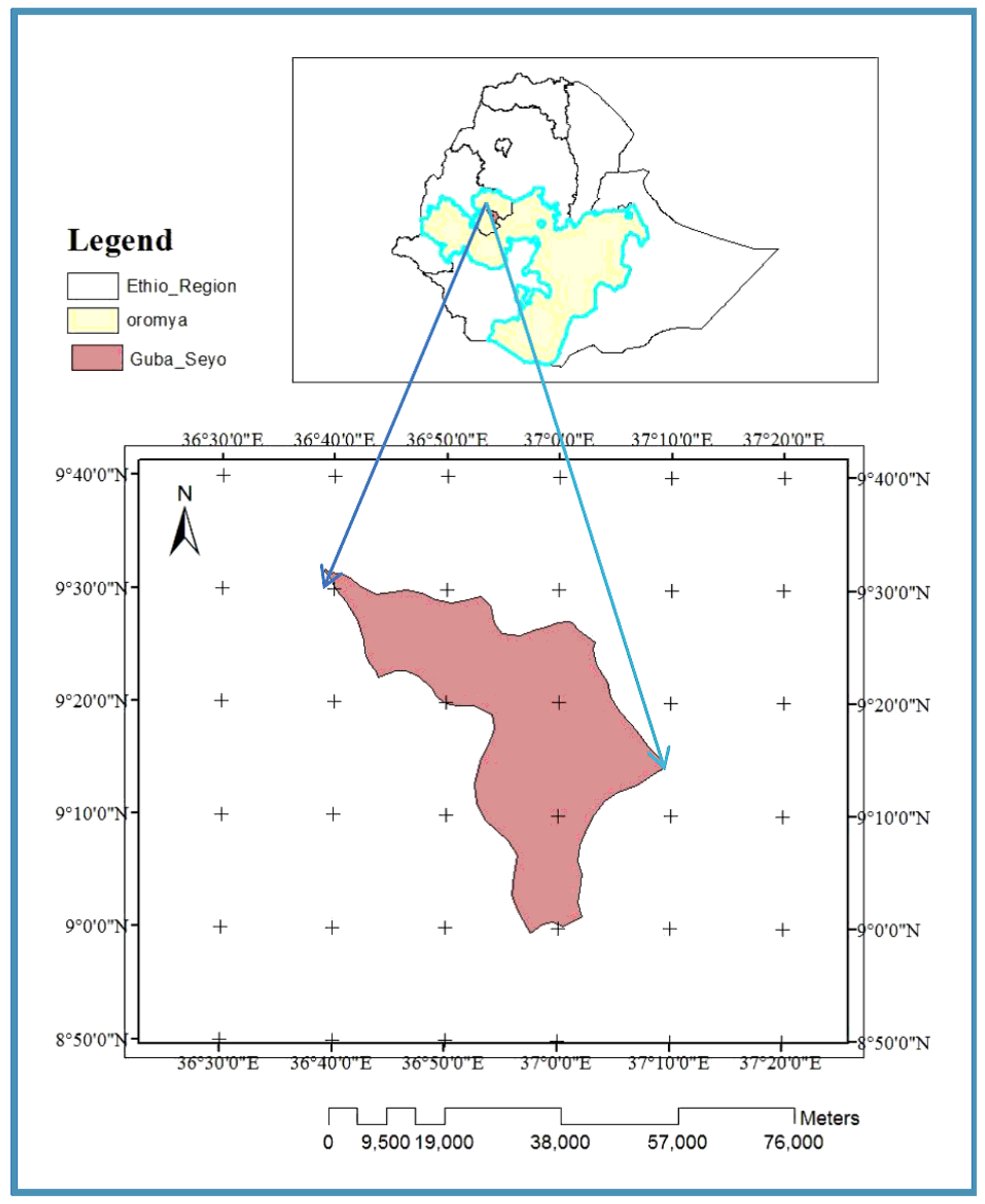

\section{Figure 1}

Map of the study area Note: The designations employed and the presentation of the material on this map do not imply the expression of any opinion whatsoever on the part of Research Square concerning the legal status of any country, territory, city or area or of its authorities, or concerning the delimitation of its frontiers or boundaries. This map has been provided by the authors. 